\title{
Silene conoidea L.: A review on its systematic, ethnobotany and phytochemical profile
}

\author{
Fazal Ullah ${ }^{1,2,4^{*}}$, Asma Ayaz ${ }^{1}$, Saddam Saqib ${ }^{1,3,4}$, Wajid Zaman ${ }^{1,34^{*}}$, Maryam Akram Butt $^{1}$ \& Asad Ullah $^{5}$ \\ ${ }^{1}$ Department of Plant Sciences, Quaid-i-Azam University Islamabad 45320, Pakistan \\ ${ }^{2}$ CAS Key Laboratory of Mountain Ecological Restoration and Bioresource Utilization, Chengdu Institute of Biology, Chinese Academy of \\ Sciences, Chengdu, China \\ ${ }^{3}$ State Key Laboratory of Systematic and Evolutionary Botany, Institute of Botany, Chinese Academy of Sciences, Beijing 100093, China \\ ${ }^{4}$ University of Chinese Academy of Sciences, Beijing 100049, China \\ ${ }^{5}$ Center of Plant Biodiversity, University of Peshawar, Pakistan
}

\section{Article history}

Received: 15 May 2019

Accepted: 25 June 2019

Published: 01 October 2019

\section{Publisher}

Horizon e-Publishing Group

\section{*Correspondence}

Wajid Zaman

凶shangla123@gmail.com

Fazal Ullah

$\bigotimes$ fazalbotanist@gmail.com

\begin{abstract}
Silene conoidea $\mathrm{L}$. is a weed commonly growing in subtropical and temperate zones of western Eurasia, and some parts of the Himalayas, as a weed in various crops like wheat, barley, lentil pea, mustard and roquette. This is the first attempt to gather detailed information about this species, viz. distribution, taxonomy, ethno-medicines, phytochemical analysis, biological activity etc. in addition to explore its therapeutic importance for future research opportunities. A total of 114 research articles were reviewed using different sources like Scopus, Web of science, Science direct, Google scholar and PubMed. The species are used for various purposes like different biological activities against microbes, bacteria and as insecticidal. Silene is also important due to high contents of various chemicals compounds. Chemical extracts contain flavones, saponins, sterols and glycosides. Traditional therapeutic values of the species for treating respiratory, antioxidant, anti-diabetic and anticancer are needed to be validated through more experiments. Ethno-pharmacological and related clinical trials also has to be formulated. A research study shows that $S$. conoidea can be used as an indicator species for gold.
\end{abstract}

Keywords: ethnobotany; biological activities; phytochemical; Silene conoidea; taxonomy

Citation: Ullah F, Ayaz A, Saqib S, Zaman W, Butt MA, Ullah A. Silene conoidea L.: A review on its systematic, ethnobotany and phytochemical profile. Plant Science Today 2019; 6(4):373-382. https://doi.org/10.14719/pst.2019.6.4.571

Copyright: (c) Ullah et al (2019). This is an open-access article distributed under the terms of the Creative Commons Attribution License, which permits unrestricted use, distribution, and reproduction in any medium, provided the original author and source are credited (https://creativecommons.org/licenses/by/4.0/).

Indexing: Plant Science Today is covered by Scopus,Web of Science, BIOSIS Previews, ESCI, CAS, AGRIS, CABI, Google Scholar, etc. Full list at http://www.plantsciencetoday.online

\section{Introduction}

Silene conoidea belonging to the family Caryophyllaceae (pink family), comprising of about 86 genera and 2,100 species throughout the world $(1,2)$ commonly distributed in temperate and alpine regions $(3,4,5)$. The genus Silene is the largest one, with about 700 species, which are mostly thriving in temperate and Mediterranean regions. All the species of this genus contains secondary metabolites, such as steroids, flavonoids and saponins (1-3). As per the present circumscription, the genus includes taxa, which were previously kept under different genera, like Coronaria, Cucubalus, Lychnis, Meldandrium, Pterocopsis and Viscaria. 
Silene conoidea is an annual herb and frequently found in crop fields in northern Temperate Asia, Punjab Plains (India, Pakistan), North Africa and Southeast Europe (4). The sprouts of $S$. conoidea are nutritive, containing carbohydrates, proteins and vitamins and it grows in wild form as well as green vegetable in many regions (5-7). This plant is of high medicinal value as its different parts are used as herbal medicine to treat different ailments. The whole plant is used to moisten the lungs, relieving cough, cooling the blood and stopping bleeding wounds (8).

Recent studies by the World Health Organization (WHO), confirmed that new resistance mechanisms are developed, which make the latest generation of antibiotics virtually ineffective (9). Scientific community have much interest in traditional medicinal plants and food as they have potential alternative antimicrobial activity $(10,11)$. Some research work has been done on the biological activity of $S$. conoidea, such as insecticidal (12), antimicrobial (13), antibacterial and allelopathic effect. Additionally, phytochemical investigations have demonstrated the presence of conoidene, glycoside and saponins $(12,14)$. The root of $S$. conoidea are rich in saponins with detergent properties and used traditionally to wash cloths as in other species of the family (12-14). In this article, we presented a review of systematic, biological activity, phytochemistry, cytogenetic and nutritional properties of this plant with special emphasis on its extensive uses in several traditional medicine systems. The data included in this paper, will be useful in designing imminent clinical trials and helpful in developing new medicines containing active components. The present work will highlight the importance of $S$. conoidea and will provide baseline data for the future research.

\section{Methodology}

Published papers were retrieved from different online bibliographical databases, and various key words were searched for "Silene conoidea" on Google Scholar, ScienceDirect Navigator, ISI Web of Knowledge, Elsevier, ResearchGate and PubMed. These key words were combined with the terms "Systematic", "Ethnobotany", "Phytochemistry" "Biological activity", "Weed" and "nutrition property" to search maximum information about the species. In the present review, we citied 114 articles from the literature related to the distribution, systematic, ethnobotany, phytochemistry, biological activity, and other aspects including, weed, effect of nitrogen and potassium and nutrition property of the species with detailed. Data were organized and tabulated using Microsoft Word. The chemical formulas of the compounds were draw on online Chem Draw software (http://chemdrawdirectcdn.perkinelmer.com).

\section{Results}

\section{Distribution}

Silene conoidea distributed in subtropical and temperate zone of western Eurasia, and some part of Himalayas, Afghanistan, China, India, Nepal, North Africa, Pakistan, South Europe, Iran, America, Jordan, Japan, Spain and Turkey, Northern Temperate Asia, the Punjab Plains (15-21). Chorotype of the species is Irano-Turanian and Mediterranean regions $(22,23)$.

\section{Taxonomy}

Annual, herbs, $20-40 \mathrm{~cm}$ high. Stem erect, branched, densely glandular. Leaves sessile 3-5 $\times$ ca. $0.4 \mathrm{~cm}$, linear-lanceolate, base clasping at the nodes. Bract present but smaller in size. Flower in terminal, paniculate, with 3-5 flowers in lax dichasia. Pedicels densely glandular pubescent. Calyx 22-26 mm long, acute, teeth lanceolate, ca. 30-nerved. Petals pink to reddish, limb 8-9 mm long, emarginated or entire, claw 14-17 mm long. Coronal scales oblong. Capsule 11-17 mm diameter conical. Seeds dark brown, ca. $1.1 \mathrm{~mm}$ long, reniform, brown $(24,25)$.

Flowering \& fruiting: Mar. - May (26); June - July (27).

\section{Biological spectrum}

Life forms are classified based on adaptation of the plants to their perennating organs to tide over the unfavorable condition. "A life form of a species is the sum of all life processes and evolved directly in response to the environment” (28). The biological spectra of the species showed that the life form of the species is therophytes and leaf size is microphylls $(29,30)$.

\section{Anatomical characters}

Epidermal wall of abaxial and adaxial surfaces of leaves were smooth to slightly wavy, with irregular and polygonal cells; stomata diacytic type with glandular and non-glandular hairs, stomata on both surfaces numerous; trichomes on abaxial surface 34-celled abundant, non-glandular, on adaxial surface glandular, 3-4-celled. The species also has different types of crystal bodies (31). The trichome characters are constant in S. conoidea showing variation in the ratio of glandular and eglandular trichomes on the inflorescence axis and outer calyx. The species have more trichome on the floral parts to protect them. Pedicles of $S$. conoidea with mostly glandular hairs (32). The species have some similar foliar epidermal characters with the previously published data on Caryophyllaceae (33-35). Overall, anatomical characters play important role in systematics of all plant species using different techniques (36-43).

\section{Palynology}

Silene conoidea bears 22-24 number of pores, which is a specific character, diameter of pore more than $4 \mu \mathrm{m}$, having in thick exine with 20 and more than 20 number of pori, pore surface cristate and the 
Table 1. Different types of trichome present on different part of the plants

\begin{tabular}{llllllllllll}
\hline Part of the plant & Stem & leaf & Inflores. & Pedicle & Anth. & Out.cal & Inn.cal & & Cal.D & Filam. & Petals \\
\hline S. conoideae & Es & Es & Es/Gs & Gs & Es & Gs & Es & Es & El & Gla
\end{tabular}

Es: eglandular short, Gs: Glandular short, El: eglandular, Gla: glabrous

surface of pollen was granulate. The species has periporate type of pollen (44). Sahreen et al. (31) mentioned that the species had reticulate surface and the number of pores ranging 32-40. Pollen of the species microrchinate-microperforate, and structure of the pollen is tectate (Table 1) (45). The palynological characters play vital role in the identification of species of the family Caryophyllaceae as well as other plant groups (4649).

\section{Cytogenetics}

The meiotic chromosome number of $S$. conoidea was $(2 n=20)$ previously that reported $(2 n=24)$ and $(n=10)$ previous study shows that the species has $\mathrm{n}=12$ which was very similar in morphology and can only be distinguish by their petal characters. $S$. conoidea was tetraploid on the basis of $\mathrm{x}=547$ but $(21,50)$ confirmed that the basic number for Silene was either $\mathrm{x}=10$ or $\mathrm{x}=12$, Silene conoidea was placed together with $S$. conica in section Conoimorpha Boiss. The species has the shortest chromosome as compared to $S$. succulenta (51). Cytomorphic variant $S$. conoidea exhibits intraspecific diversity in the form of different cytotypes accompanied by variation in some of the morphological features, which was $(2 n=20,40)(52)$. S. conoidea has XY type of DNA. Number of copy is one, while length of base pair 6236, covered area 1(intron)-15, number of PCR fragments were 9, posterior probabilities 0.9980 . Silene conoidea and $S$. conica represent section Conoimorpha, group together with strong support. Size of Base pair 147,896, while IR size base pair 26,828 , GC content $36 \%$, Protein 77 , tRNA 30, rRNA 4 and Introns 17 (Table 2) (53).

Table 2. Sequenced plastid genomes in Silene conoidea

\begin{tabular}{lccccc}
\hline $\begin{array}{c}\text { Plant } \\
\text { name }\end{array}$ & $\begin{array}{c}\text { Size } \\
\text { (bp) }\end{array}$ & $\begin{array}{c}\text { IR size } \\
\text { (bp) }\end{array}$ & $\begin{array}{c}\text { GC } \\
\text { content } \\
(\%)\end{array}$ & $\begin{array}{c}\text { Gene } \\
\text { (protein/ } \\
\text { tRNA/ } \\
\text { rRNA }\end{array}$ & Introns \\
\hline $\begin{array}{l}\text { Silene } \\
\text { conoidea }\end{array}$ & 147,896 & 26,828 & 36.0 & $77 / 30 / 4$ & 17 \\
\hline
\end{tabular}

\section{Ethnobotanical uses}

Ethnobotany, the study of how the people of an area use indigenous plants in their basic health and other needs. Ethnobotany is defined "the study of the relationship which exists between people of primitive societies and their environment” (54-57). Some of the ethnobotanical uses of the species were mentioned in literature are given below.

Fresh leaves paste are made and applied typically for skin infection (58-61). Whole plant used as emollient and used bath or as fumigant (6265 ) paste of the seed and leaves applied on pimples and backache (66). Areal part of the plant also used to mixed with vegetable as well as a fodder $(26,67)$. Fresh plant paste is used in curing pimples and backache (59). The seed and young leaves of the plant are used in backache and applied on pimples (68). The species also used as fodder and forage (69). The root of the plant is used as emollient to wash wounds and hair, fumigant, juice used in opthalmia (70). Fresh and dried leaves of the plant cooked and used as vegetable and as stomachic (71). In combination with Asplenium dalhousiae Hook. and Rubia cordifolia L., leaves of S. conoidea crushed and juice obtained is applied to cure blisters (72-75). Whole plant is used to moisten the lungs, relieve cough, cool the blood and stop bleeding from wounds (8).

\section{Phytochemical overview}

The medicinal properties of $S$. conoidea have been attributed to flavonoid's glycosides. Glycoside a condensed compound obtained from sugar and non-sugar compound and may have further components, such as ring structure that are substituted and non-substituted. Key characteristic Phytochemical constituents in S. conoidea were conoidene, C-Glycosylflavones (76). Phytoecdysteroids were absent in S. conoidea (77, 78). While other species of the genus have ecdysteroids (79).

\section{Flavonoids and Glycosides}

Two new chemical compounds were isolated from $S$. conoidea C-Glycosylflavones by using butanolsoluble part of methanolic extract, these two new flavonoids and glycosides having C-C linkage between $\mathrm{C}-8$ and $\mathrm{C}-1$. 8-C(4-O- $\mathrm{-}-\mathrm{L}-$ rhamnopyranosyl)- $\beta$-D-glucopyroanosyldiosmetin (1) and 8-C-(4-O- $\alpha$-L-rhamnopyranosyl)- $\beta$-Dglucopyranosylapigenin (76). These both glycosides were extracted using HPLC and were identified by using spectroscopic. Additionally, they also study 12, a-spinasterol and its glycoside were also carried out for the first time.

\section{Conoidene}

$\mathrm{R}_{1}=\beta$-D-Glcp- $4 \leftarrow \alpha-\mathrm{L}-\mathrm{Phap}$

$\mathrm{R}_{2}=\mathrm{OH}, \mathrm{R}_{3}=\mathrm{Me}$

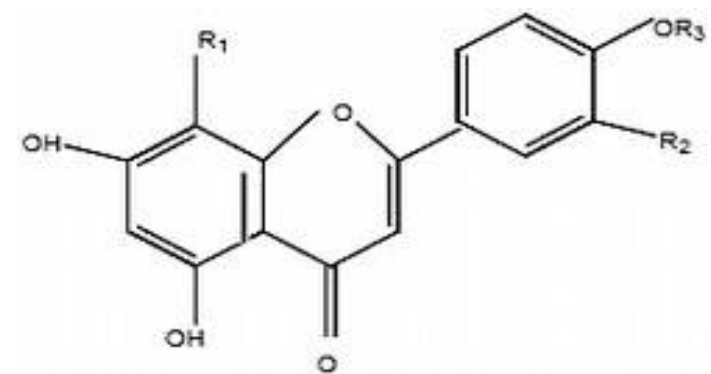

Fig. 1. chemical structure of 8(4"-O- $\alpha$-L-rhamnopyranosyl)-C- $\beta$ D glycopyranosyldiosmetin isolated from $S$. conoidea 
$\mathrm{R}_{1}=\beta$-D-Glcp- $4-1$ - $\mathrm{a}-\mathrm{L}-\mathrm{Rh}$ ap

$\mathrm{R}_{2}=\mathrm{H}, \mathrm{R}_{3}=\mathrm{H}$<smiles>[R20]c1ccc(-c2cc(=O)c3c(O)c([R3])c(O)c([R2])c3o2)cc1O</smiles>

Fig. 2. Chemical compound extracted from S. conoidea 8 (4"-O$\alpha$-L-rhamnopyanosyl)-C- $\beta$-D-glucopyranosylapigenin

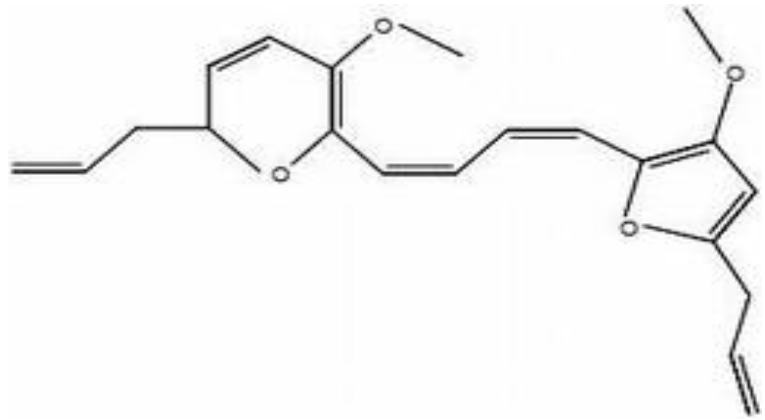

Fig. 3. Conoidene (2,2'-(1,3-butadiene-1,4-diyl) bis[3-methoxy-5(2-propen-1-yl) furan) obtain from $S$. conoidea

Conoidene in $S$. conoidea are present; three chemical compounds were extracted from $S$. conoidea were 8(4"-O-a-L-rhamnopyranosyl)C- $\beta$-D-glycopyranosyldiosmetin, 8 (4"-O- $\alpha-\mathrm{L}-$ rhamnopyanosyl)-C- $\beta$-D-glucopyranosylapigenin and Conoidene (2,2'-(1,3-butadiene-1,4-diyl)bis [3-methoxy-5-(2-propen-1-yl) furan). The conoidene 1,4-di-[3-methoxy-5-(2-propenyl)furan]-1,3 butadiene (1), were isolated from ethyl acetate soluble fraction of methanolic extract (14) (Fig 1, 2, 3).

\section{Saponins and their sterol and glycoside}

Silene conoidea showed the presence of saponins which are used in washing detergents property $(12,14)$; it also has a-Sapinasterol and $a-$ Spinasterol-glyucoside, both are differ from each other on alkyl group (78) (Fig. 4).

a-Spinasterolglucoside $\mathrm{R}=\mathrm{H}$

a-Spinasterolglucoside $\mathrm{R}=\mathrm{O}-\beta$-D-Glu

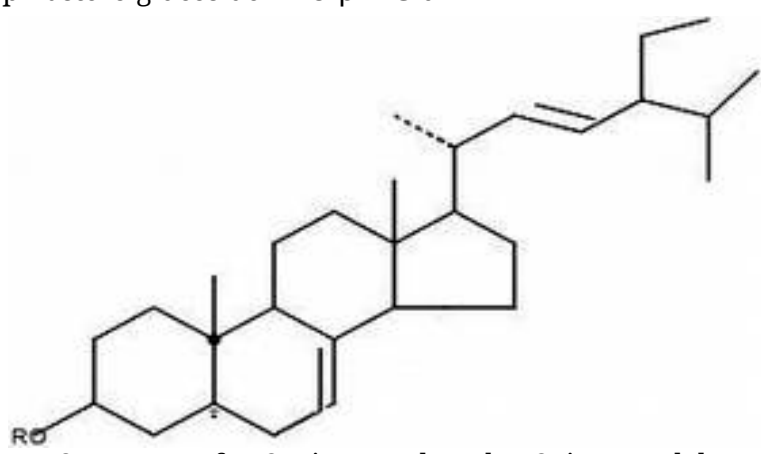

Fig 4. Structure of a-Sapinasterol and a-Spinasterolglucoside isolated from $S$. conoidea

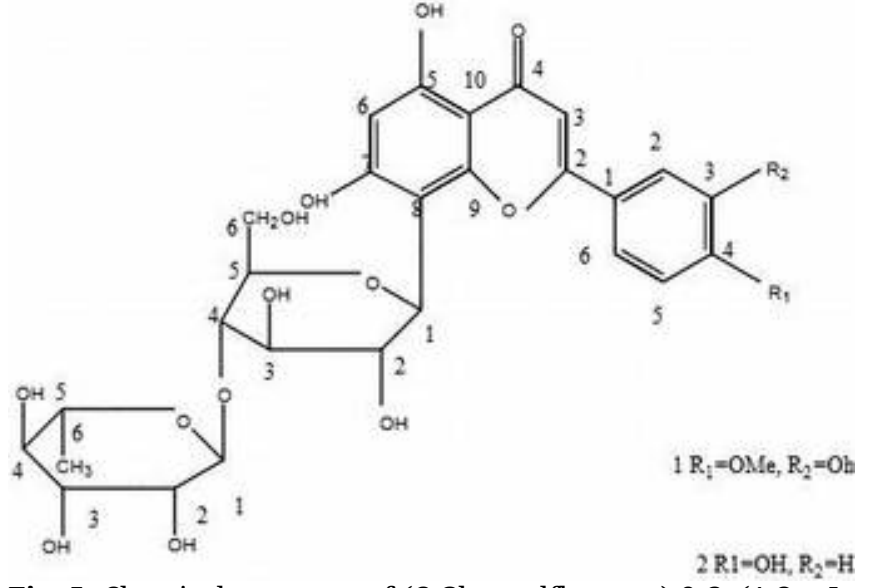

Fig. 5. Chemical structure of (C-Glycosylflavones) 8-C -(4-O-a-Lrhamnopyranosyl)- $\beta$-D-glucopyranosylapigenin and two known steroids: $\alpha$-Spinasterol and $\alpha$-spinosterolglucoside isolated from S. conoidea (67)

\section{C-Glycosylflavones}

8-C-(4-O- $\alpha$-L-rhamnopyranosyl)- $\beta$-D-

glucopyranosylapigenin and two known steroids:a-Spinasterol and a-spinosterolglucoside was isolated from S. conoidea (76) (Fig. 5).

\section{Other compounds}

The isolation of some chemical compounds from the species were Vitexin 4"-a-L-Rhamnopyrasnosyl (76).

$$
\mathrm{R} 1=\mathrm{R} 2=\mathrm{H}
$$

R3 = $\beta$-D-Glcp-4־1- $\alpha$-L-Rhap

\section{Biogeochemical}

$S$. conoidea possesses high concentration of gold $303 \mathrm{ppb}$, therefore the species considered indicator for gold. The species has a significant result and generates anomalies of $\mathrm{Au}$ and its pathfinder (80).

\section{Heavy metals}

The prepared samples by acid digestion, followed by quantification of selected trace metals by using atomic absorption spectrophotometer (Table 3, 4, 5) (81).

Table 3. Accumulation factors of trace metals (mean+SD) in Silene conoidea

\begin{tabular}{cccccccc}
\hline $\begin{array}{c}\text { Trace } \\
\text { element }\end{array}$ & $\mathrm{Fe}$ & $\mathrm{Zn}$ & $\mathrm{Cu}$ & $\mathrm{Mn}$ & $\mathrm{Cr}$ & $\mathrm{Cd}$ & $\mathrm{Pb}$ \\
\hline \multirow{3}{*}{ Value } & 553.5 & 17.17 & 2.96 & 19.01 & 7.71 & 3.69 & 3.01 \\
& \pm & \pm & \pm & \pm & \pm & \pm & \pm \\
& 175.30 & 8.16 & 0.87 & 7.55 & 3.10 & 1.25 & 1.69 \\
\hline
\end{tabular}

Table 4. Concentration $(\mathrm{mg} / \mathrm{kg}$, dry weight) of trace metals in Silene conoidea

\begin{tabular}{ccccccccc}
\hline $\begin{array}{c}\text { Trace } \\
\text { element }\end{array}$ & Fe & Zn & $\mathrm{Cu}$ & $\mathrm{Mn}$ & $\mathrm{Cr}$ & $\mathrm{Cd}$ & $\mathrm{Pb}$ & $\begin{array}{l}\text { To } \\
\text { tal }\end{array}$ \\
\hline & 0.45 & 0.40 & 0.14 & 0.05 & 0.24 & 4.99 & 0.13 & \\
Value & \pm & \pm & \pm & \pm & \pm & \pm & \pm & 6.41 \\
& 0.18 & 0.11 & 0.06 & 0.02 & 0.12 & 2.31 & 0.07 & \\
\hline
\end{tabular}


Table 5. Health risk index of trace metals (mean+SD) associated with the consumption of different

\begin{tabular}{cccccccc}
\hline $\begin{array}{c}\text { Trace } \\
\text { element }\end{array}$ & $\mathrm{Fe}$ & $\mathrm{Zn}$ & $\mathrm{Cu}$ & $\mathrm{Mn}$ & $\mathrm{Cr}$ & $\mathrm{Cd}$ & $\mathrm{Pb}$ \\
\hline Value & 0.043 & 0.001 & 0.002 & 0.005 & 0.137 & 0.046 & 0.037
\end{tabular}

\section{Biological activity}

To manage plant diseases scientist are working on the plant extracts (82). Nowadays, natural products especially those which are extracted from plants, gaining more interest for the management of different abnormalities. These gain more importance than synthetic drugs due to negligible side effects and resistance (83). Some of the biological activities mentioned in previous literature for $S$. conoidea are given below.

\section{Insecticidal activity}

Phytoecdycteroids are analogues of insect molting hormones and their concentration in plants can reach 0.01\%-3\%. Their low concentrations affect insect development. E.gecdycteroid 20 hydroxyecdysone at concentration of $10-8$ to $10-9 \mathrm{M}$ are initiates the transformation occurring in embryogenesis and during larval development with instant metamorphosis to the adult insect 20. The potential insect deterrent activity of $S$. conoidea have been reported $(66,84)$. The species have the potential and also being used as insect repellent (66).

\section{Antibacterial activity}

The extracts of $S$. conoidea showed antibacterial activity against Pseudomonas aeruginosa, Salmonella typhimurium, Staphylococcus aureus and $S$. epidermidis. Extract of the species were made using solvent extraction ( $5 \mathrm{~g}$ ) of air dried and powder material were mixed with $500 \mathrm{ml}$ of various solvent like methanol, n-Hexane and ethylacetate. The supernatant was filtered using Whatman No. 4 filter paper and then concentrated to dryness at low temperature $\left(40^{\circ} \mathrm{C}\right)$ using rotary evaporator and at last the extract were dissolved in diamethyl sulfoxide to yield $20 \mathrm{mg} / \mathrm{ml}$ of the extract (62). 0.69g extract from ethanol solvent were used, which percentage yield 3.0, they showed inhibition against bacterial strain in millimeter (85) (Table 6).

Table 6. Zone of inhibition in millimeter of Silene conoidea extract against the bacterial strains

\begin{tabular}{lllll}
\hline Bacteria & $\begin{array}{l}\text { Staphylo- } \\
\text { coccus } \\
\text { epidermidis }\end{array}$ & $\begin{array}{l}\text { Staphylo- } \\
\text { coccus } \\
\text { aureus }\end{array}$ & $\begin{array}{l}\text { Salmo- } \\
\text { nella } \\
\text { typhimuri } \\
\text { um }\end{array}$ & $\begin{array}{l}\text { Pseudo- } \\
\text { monas } \\
\text { aeruginos } \\
\text { a }\end{array}$ \\
\hline $\begin{array}{l}\text { Inhibition } \\
\text { Against }\end{array}$ & 1 & 2 & 1 & 10 \\
$\begin{array}{l}\text { Bacteria } \\
\text { Strains in }\end{array}$ & & & & 10 \\
Mm & & & & \\
\hline
\end{tabular}

\section{Antimicrobial activity}

Microbes cause various diseases in human beings from mild to acute and chronic. Different solvent extract of $S$. conoidea plant have been reviewed against a range of microorganisms affecting not only humans but also animals. Different plant species used in traditional medicines for the treatment of common, sore throat, fever, cold and also as aromatic incense showed anti-microbial activity in pharmacological assessments (54). Dried and powder material (50g) of the species were extracted with methanol $(300 \mathrm{ml})$ in a soxhlet for 10-12 hours. Solvent were removed in vacuum to give concentrated extract and the residue kept in the refrigerator until use. These residues after dilution with methanol were injected to different microorganism. Screening was performed on the plates of Mulller-Hinton Agar (Oxoid); these were sterilized for $15 \mathrm{~min}$ at $121^{\circ} \mathrm{C} .20 \mathrm{ml}$ of this medium was added to each sterile Petri dish (approximately $20 \times 100 \mathrm{~mm}$ ) and kept for 24 hours to control sterility (13) (Table 7).

Table 7. Antimicrobial activity of Silene conoidea

\begin{tabular}{ll}
\hline Botanical Name & Silene conoidea \\
\hline M1 & Bacillus subtilis (No Effect) \\
\hline M2 & Candida albicans (No Effect) \\
\hline M3 & Escherichia coli (No effect) \\
\hline M4 & Klebsiella pneumonia (No effect) \\
\hline M5 & Morganella morganii (No effect) \\
\hline M6 & Pseudomonas aeruginosa (Significant) \\
\hline M8 & Salmonella typhi (No effect) \\
\hline Part of plant & Staphylococcus aureus (Significant) \\
\hline
\end{tabular}

The shade dried samples of $S$. conoidea were grounded separately using electric grinder to make a fine powder. Solvent extraction $(5 \mathrm{~g})$ of air dried and fine powder of $S$. conoidea were mixed with $500 \mathrm{ml}$ of three solvent methanol, n-Hexane and ethylacetate. The supernatant was filtered using Whatman No. 4 filter paper and for the concentration were dryness at low temperature $\left(40^{\circ} \mathrm{C}\right)$. They were concentrated using rotary evaporator and at last the extract was dissolved in dimethyl sulfoxide to yield $20 \mathrm{mg} / \mathrm{ml}$ of the extracts. The extracted samples were stored at $4^{\circ} \mathrm{C}$ in sterile airtight vials for further research. $S$. conoidea extracts were used against these microbes in vitro antibacterial activities, five gram-negative bacteria were used for the study: Escherichia coli, Klebsiella pneumonia, Yersinia pestis, Shigella sonnei, Pseudomonas aeruginosa and four gram-positive bacteria; Staphylococcus aureus, S. epidermidis, Micrococcus luteus, Listeria monocytogenes were also studied and one fungal strain Candida albicans using concentration of $20 \mathrm{mg} / \mathrm{ml}$. S. conoidea does not show any active activity against Escherichia coli, Staphylococcus aureus, Shigella sonnei, Klebsiella pneumonia and Pseudominas aeruginosa. The methanolic extract 
of S. conoidea showed activity against Staphylococcus epidermidis zone of inhibition were 10.6+0.57. Ethylacetate extracts show positive results against $S$. epidermidis inhibition were $(13+0)$. Methanolic extract Inhibition activity against Salmonella paratyphi showed $(9.6+1.15)$. Hexane and ethylacetate extract inhibited $(9+0)$ $\mathrm{mg} / \mathrm{ml}$ and $(11+0)$ respectively against Salmonella typhimurium. The ethylacetate extract showed $(11+0)$ inhibition against Listeria monocytogene. Ethylacetate extract of the species inhibition result were $(13.3+0.57)$ (62). Antimicrobial activity of $S$. conoidea showed response against Basillus sp., Escherichia coli, Klebsiella sp., Morganella morganii, Pseudomonas aeruginosa, Salmonella typhimirium and Staphylocoocus sp. (86).

\section{Antifungal activity against Candida albicans}

The result showed inactive against antifungal activity three solvent methods were used i.e. methanol, n-Hexane and ethylacetate on fungi Candida albicans (62).

\section{Allelopathic effect}

Allelopathy is beneficial or harmful influence of chemical substances released by the plant species, which can suppress or promote the growth of nearby plants or microorganism. Allelopathic affect may be present in all plant organs, including root, rhizome, stem, leaves, flowers, fruits and seeds, some of which can store these compounds. The quantity and emission pathway different from species to species (87) Stem and root of $S$. conoidea inhibited the growth of wheat seedling, while the leaves are promoted growth due to allelopathy (88).

\section{Other aspects of Silene conoidea}

\section{Weed}

Unwanted plant which effects the crops of a specific area is known as weed (89). Silene conoidea growing in many crop fields is a weed used as fodder. The plant is very common weed of wheat crop (90-102). It can affect the harvest of wheat significantly (103-105). Research on ecological interpretation of weed vegetation in the summer crop fields of Anhui Province, China revealed that $S$. conoidea is a common weed in the research area (51, 106-109). It is a common weed of different crops such as, barely, mustard, roquette, lentil pea field in district Sriganganagar (110); also commonly occurring in cotton field as weed (111, 112).

\section{Effect of Nitrogen and potassium}

Using matrix culture of nitrogen and potassium can affect the morphology of $S$. conoidea vigorously. The study showed that the plant height, stem diameter, leaf length, leaf width, root length and leaf area were increased with the scope of $8.0 \mathrm{mmol} / \mathrm{L}$ nitrogen level and $5.0 \sim 8.0 \mathrm{mmol} / \mathrm{L}$ potassium level, they help in the growth of the plant tremendously. S. conoidea yield best under the condition of $8.0 \sim 12.0 \mathrm{mmol} / \mathrm{L}$ nitrogen and $5.0 \sim 7.5 \mathrm{mmol} / \mathrm{L}$ potassium (113).

\section{Nutrition property}

S. conoidea is a common herbaceous weed occurring in the wild. The nutrient contents were studied, the result showed that $S$. conoidea contained abundant nutrients, e.g. calcium, potassium, magnesium, iron and manganese. Heavy metal cadmium and lead were also reported but present in safe amount. Soluble sugar, vitamin $\mathrm{C}$ and carotene were also detected as rich in occurrence (114).

\section{Conclusion}

Silene conoidea is used in traditional medicine in different geographic areas of the world. The anatomical, palynological and cytogenetic studies attribute it a separate identity from the rest of the species of Silene.

This review emphasizes that the systematic, ethnobotanical, phytochemical and biological activities of $S$. conoidea emphasized its importance globally. The available research data on $S$. conoidea signifies its importance as medicinal plant in a wide range of ethnobotanical uses especially for the treatment of skin infection, backache, pimple, emollient, fumigant and as vegetable. The medicinal properties of $S$. conoidea are attributed to the presence of variety of chemicals (Fig. 1 to 5) like flavones, glycosides, conoidene etc. The increasing medicinal importance of $S$. conoidea is demanding the investigation and discovery of more potential phytochemicals. Such research works can lead to the improvement in drug system by discovering new chemicals for the welfare of humankind.

The ethno-pharmacological study of the plant is necessary to check its action for different disorders. Biological activities of plants are more important to use a specific part to check antimicrobial, insecticidal, antibacterial properties. Till date, $S$. conoidea is studied for four biological activities. Further research work will be carried out to elucidate all the possible biological activities of the species.

\section{Authors' contributions}

FU, WZ, SS and AA designed, conceived the presented ideas and wrote the manuscript; $\mathrm{MAB}$ and $\mathrm{AU}$ analyzed the data; all authors revised and approved the final version of the manuscript.

\section{Conflict of interest}

The authors have no conflict of interest. 


\section{Acknowledgments}

Authors pay special thanks to the anonymous reviewers for their valuable comments on the earlier version of this article.

\section{References}

1. Perveen A, Qaiser M. Pollen flora of Pakistan-LICaryophyllaceae. P J Bot. 2006;38(4):901-915.

2. Chopin MJ, Bouillant M-L, Wagner H, Galle K. Endgültige struktur von schaftosid aus Silene schafta. Phytochemistry. 1974;13(11):2583-86. https://doi.org/10.1016/S0031-9422(00)86940-X

3. Saatov B. Usmanov, and NK Abubakirov. Khim Prir Soedin. 1979;793-97.

4. Khoshoo T, Bhatia S. Cytology of some Rubiaceae of the north-western Himalayas. Proceedings: Plant Sciences. 1963;58(1):36-44.

5. Goering K, Rao P. New Starches. VII. The Properties of the Starch from Silene conoidea. Starch-Stärke. 1969;21(9):228-31.

https://doi.org/10.1002/star.19690210903

6. Ali MS, Saleem M, Akhtar F, Jahangir M, Parvez M, Ahmad VU. Three p-cymene derivatives from Zataria multiflora. Phytochemistry. 1999;52(4):685-88. https:// doi.org/10.1016/S0031-9422(99)00259-9

7. Ali H, Qaiser M. Contribution to the Red List of Pakistan: a case study of the narrow endemic Silene longisepala (Caryophyllaceae). Oryx 2011;45(4):522-27. https://doi.org/10.1017/S003060531000102X

8. Liu Y-J, Wang J-H, Ma Q-L, Zhang D-K. Floristic analysis of desert spermatophyte families in Gansu Province J. Hortic. Sci. 2008;5:007.

9. Mahomoodally MF, Dilmohamed S. Antibacterial and antibiotic potentiating activity of Vangueria madagascariensis leaves and ripe fruit pericarp against human pathogenic clinical bacterial isolates. J Tradit Complement Med. 2016; 6(4):399-403.

10. Wang J-H, Luan F, He X-D, Wang Y, Li M-X. Traditional uses and pharmacological properties of Clerodendrum phytochemicals. J Tradit Complement Med 2017. https://doi.org/10.1016/j.jtcme.2017.04.001

11. Akhtar MS, Hossain MA, Said SA. Isolation and characterization of antimicrobial compound from the stem-bark of the traditionally used medicinal plant Adenium obesum. J Tradit Complement Med 2017;7(3):296-300.

https://doi.org/10.1016/j.jtcme.2016.08.003

12. Nasir E, editor Flora of Pakistan. Agriculture Research Conference, 1981, Islamabad (Pakistan), 24-27 Oct 1981; 1981: PARC.

13. Bazzaz B, Haririzadeh G. Screening of Iranian plants for antimicrobial activity. Pharm Biol. 2003;41(8):57383. https://doi.org/10.1080/13880200390501488

14. Ahmad V, Ali Z, Ali M, Zahid M. Chemical constituents of Silene conoidea. Fitoterapia 1998;69(5):406-8.

15. R RAJBHANDARI K, SUZUKI M. Distribution maps of Silene (Caryophyllaceae) in Nepal (I). Bulletin of the Tohoku University Museum 2008;8:9-28.

16. Khansari A, Khorasani N, Ramezani M, Esphandabad BS. Analysis of Plant Diversity of Iranian Oak
Ecosystem Using Multivariate Statistical Methods (Case Study: Javanrod City-Kermanshah City). OJE. 2016;6(09):545. https://doi.org/10.4236/oje.2016.69052

17. Yavari A, Shahgolzari S. Floristic study of KhanGormaz protected area in Hamadan province, Iran Int J Agric Biol. 2010;12:271-75.

18. Rajaei P, Maassoumi A, Mozaffarian V, Nejad Sattari T, Pourmirzaei A. Alpine flora of Hezar mountain (SE Iran). Rostaniha 2011;12(2):111-27.

19. Amiri F, Shariff ARBM. Application of geographic information systems in land-use suitability evaluation for beekeeping: A case study of Vahregan watershed (Iran). Afr. J. Agric. Res. 2012;7(1):89-97. https://doi.org/10.5897/AJAR10.1037

20. Oran SAS. Flora of Bader Al-Jadida County, western high mountains of Amman city/Jordan. Int. J. Herb. Med. 2015;3(4 Part A):49-59.

21. Ghazanfar SA. Cytological Studies in the Genus Silene L. New Phytol. 1983;93(1):123-7. https://doi.org/10.1111/j.1469-8137.1983.tb02697.x

22. Roshan Sa, Heydari M. Flora, life form and chorological study of Quercus brantii habitat in Emamzadeh Abdullah woodland, Iran. Biodiversitas ] Bio Div. 2014;15(2):245-50 https://doi.org/10.13057/biodiv/d150219

23. Mataji A, Daliri HK, Babaie S, Jafari S, Roshan SA. Flora diversity in burned forest areas in Dehdez, Iran. Folia Forestalia Polonica, Seria A-Forestry 2013;55(1):33-41. https://doi.org/10.2478/ffp-2013-0005

24. Rechinger KH, Aellen P. Flora of lowland Iraq: JSTOR; 1964

25. Ullah Jan H, Jan A, Khan Shinwari Z. Distribution of weeds in wheat fields of district Bannu, Khyber Pakhtunkhwa Pakistan. Pak J Weed Sci Res. 2012;18(3):393-411.

26. Rawat DS, Kharwal AD. Ethnobotanical studies of weed flora in Shivalik Hills, Himachal Pradesh, India. Int J of Adv Res. 2014;2(5):218.

27. Ullah I, Wazir SM, Faroog A, Khan SU, Hussain Z. Identification of common weeds and its distribution pattern in wheat fields of FR Bannu, Khyber Pakhtunkhwa, Pakistan. Pak J Weed Sci Res. 2011;17(4):407-16.

28. Reddy SC, Krishna HP, Meena S, Bhardwaj R, Sharma $\mathrm{K}$. Composition of life forms and biological spectrum along climatic gradient in Rajasthan, India. Int. J. Environ. Sci. 2011;1(7):1639-42.

29. Sher Z, Hussain F, Badshah L, Wahab M. Floristic composition, communities and ecological characteristics of weeds of wheat fields of Lahor, District Swabi, Pakistan. Pak J Bot. 2011;43(6):2817-20.

30. Ejtehadi H, Amini T, Kianmehr H, Assadi M. Floristical and chorological studies of vegetation in Myankaleh wildlife refuge, Mazandaran province, Iran. Iranian Int J Sci. 2003;4(2):107-20.

31. Sahreen S, Khan MA, Khan MR, Khan RA. Leaf epidermal anatomy of the genus Silene (Caryophyllaceae) from Pakistan. Biodivers Conserv. 2010;3(1):93-102.

32. Hoseini E, Ghahremaninejad F, Assadi M. The indumentum of vegetative and reproductive parts of annual Silene L. species (Caryophyllaceae) in Iran. $\mathrm{P}$ Bio Sci. 2016;6(1):107-16. 
33. Ullah F, Papini A, Shah SN, Zaman W, Sohail A, Iqbal M. Seed micromorphology and its taxonomic evidence in subfamily Alsinoideae (Caryophyllaceae). Microsc Res Techniq. 2019;82(3):250-59. https://doi.org/10.1002/jemt.23167

34. Ullah F, Zafar M, Ahmad M, Shah SN, Razzaq A, Sohail A, et al. A systematic approach to the investigation of foliar epidermal anatomy of subfamily Caryophylloideae (Caryophyllaceae). Flora. 2018;246247:61-70. https://doi.org/10.1016/j.flora.2018.07.006

35. Ullah F, Zaman W, Papini A, Zafar M, Shah SN, Ahmad $\mathrm{M}$, et al. Using multiple microscopic techniques for the comparative systematic of Spergula fallax and Spergula arvensis (Caryophyllaceae). Microsc Res Techniq. https://doi.org/10.1002/jemt.23176

36. Ashfaq S, Ahmad M, Zafar M, Sultana S, Bahadur S, Ullah F, et al. Foliar micromorphology of Convolvulaceous species with special emphasis on trichome diversity from the arid zone of Pakistan. Flora. https://doi.org/10.1016/j.flora.2019.04.007

37. Attar F, Esfandani-Bozchaloyi S, Mirtadzadini M, Ullah F, Zaman W. Foliar and stem epidermal anatomy of the tribe Cynoglosseae (Boraginaceae) and their taxonomic significance. Microsc Res Techniq. 2019;82(6):786-802. https://doi.org/10.1002/jemt.23223

38. Kandemir N, Çelik A, Ullah F, Shah SN, Zaman W. Foliar epidermal anatomical characteristics of taxa of Iris subg. Scorpiris Spach (Iridaceae) from Turkey. Microsc Res Techniq. 2019;82(6):764-74. https://doi.org/10.1002/jemt.23221

39. Shah SN, Ahmad M, Zafar M, Malik K, Rashid N, Ullah $\mathrm{F}$, et al. A light and scanning electron microscopic diagnosis of leaf epidermal morphology and its systematic implications in Dryopteridaceae: Investigating 12 Pakistani taxa. Micron. 2018;111:3649. https://doi.org/10.1016/j.micron.2018.05.008

40. Shah SN, Ahmad M, Zafar M, Razzaq A, Malik K, Rashid N, et al. Foliar epidermal micromorphology and its taxonomic implications in some selected species of Athyriaceae. Microsc Res Techniq. 2018;81(8):902-13. https://doi.org/10.1002/jemt.23055

41. Shah SN, Ahmad M, Zafar M, Ullah F, Zaman W, Malik $\mathrm{K}$, et al. Taxonomic importance of spore morphology in Thelypteridaceae from Northern Pakistan. Microsc Res Techniq. 2019;82(8):1326-33.

42. Shah SN, Ahmad M, Zafar M, Ullah F, Zaman W, Mazumdar J, et al. Leaf micromorphological adaptations of resurrection ferns in Northern Pakistan. $\quad$ Flora. 2019;255:1-10. https://doi.org/10.1016/j.flora.2019.03.018

43. Gul S, Ahmad M, Zafar M, Bahadur S, Celep F, Sultana $\mathrm{S}$, et al. Taxonomic significance of foliar epidermal morphology in Lamiaceae from Pakistan. Microsc Res Tech. 2019:1-22. https://doi.org/10.1002/jemt.23316

44. Sahreen S, Khan MA, Meo AA, Jabeen A. Pollen morphologynof the genus Silene (SileneaeCaryophyllaceae) from Pakistan. Biodivers. Conserv. 2008;1(2):74-85.

45. Pejhanmehr M, Edalatiyan MN. The importance of palynology in the taxonomy of genus Silene, based on pollen morphology.
46. Ullah F, Nasar Shah S, Zaman W, Zafar M, Ahmad M, Ayaz A, et al. Using palynomorphological characteristics for the identification of species of Alsinoideae (Caryophyllaceae): a systematic approach. Grana 2019;58(3):174-84 https://doi.org/10.1080/00173134.2019.1569719

47. Ullah F, Zafar M, Ahmad M, Dilbar S, Shah SN, Sohail A, et al. Pollen morphology of subfamily Caryophylloideae (Caryophyllaceae) and its taxonomic significance. Microsc Res Techniq. 2018;81(7):704-15. https://doi.org/10.1002/jemt.23026

48. Gul S, Ahmad M, Zafar M, Bahadur S, Sultana S, Begum N, et al. Taxonomic study of subfamily Nepetoideae (Lamiaceae) by polynomorphological approach. Microsc Res Tech. 2019;82(7):1021-31. https://doi.org/10.1002/jemt.23249

49. Esfandani-Bozchaloyi S, Zaman W. Taxonomic significance of macro and micro-morphology of Geranium L. species Using Scanning Electron Microscopy. Microsc Res Techniq. 2018;81(12):152032. https://doi.org/10.1002/jemt.23159

50. Bari EA. Cytological Studies in the Genus Silene L. New Phytol. 1973;72(4):833-8. https://doi.org/10.1111/j.14698137.1973.tb02059.x

51. Badr A, MA H. Cytology and taxonomic relationships of some taxa in the genus Silene L. Cytologia 1987;52(1):63-8. https://doi.org/10.1508/cytologia.52.63

52. Rani S. Exploration and evaluation of cytomorphological diversity in Polypetalae from district Kangra (Himachal Pradesh). [dissertation]. Punjab: Punjabi University; 2012.

53. Rautenberg A, Filatov D, Svennblad B, Heidari N, Oxelman B. Conflicting phylogenetic signals in the SIX1/Y1 gene in Silene. BMC evolutionary biology. 2008;8(1):299. https://doi.org/10.1186/1471-2148-8-299

54. Schultes RE. The role of the ethnobotanist in the search for new medicinal plants. Lloydia 1962;25:25766.

55. Shinwari S, Ahmad M, Luo Y, Zaman W. Quantitative analyses of medicinal plants consumption among the inhabitants of shangla-kohistan areas in NorthernPakistan. P J Bot. 2017;49(2):725-34.

56. Zeb S, Zaman W, Zeb S, Ali S, Ullah F, Shakoor A. Pharmacology, Taxonomy and Phytochemistry of the genus Artemisia specifically from Pakistan: a comprehensive review. harm. Biomed. Res. 2017;4(4):1-12. https://doi.org/10.18502/pbr.v4i4.543

57. Ullah F, Shah S, Zaman W, Ali C, Gul S, Saqib S, et al. Traditional knowledge of medicinal herbs among indigenous communities in Maidan Valley, Lower Dir, Pakistan. Bull Env Pharmacol Life Sci. 2018;7:01-23.

58. Abbasi AM, Khan MA, Shah MH, Shah MM, Pervez A, Ahmad M. Ethnobotanical appraisal and cultural values of medicinally important wild edible vegetables of Lesser Himalayas-Pakistan. J Ethnobiol Ethnomed. 2013;9(1):66. https://doi.org/10.1186/1746$\underline{4269-9-66}$

59. Rehman K, Khan MA, Ullah Z, Chaudhary HJ. An ethno botanical perspective of traditional medicinal plants from the Khattak tribe of Chonthra Karak, Pakistan. J Ethnopharmacol. 2015;165:251-9. 
60. Ali H, Qaiser M. The ethnobotany of Chitral valley, Pakistan with particular reference to medicinal plants. Pak J Bot. 2009;41(4):2009-41.

61. Ahmad S, Ali A, Beg H, Dasti AA. Ethnobotanical studies on some medicinal plants of booni valley, district chitral pakistan. Pak J Weed Sci Res. 2006;12(3):183-90.

62. Shinwari ZK, Malik S, Karim AM, Faisal R, Qaiser M. Biological activities of commonly used medicinal plants from Ghazi Brotha, Attock district. Pak J Bot. 2015;47(1):113-20.

63. Jabeen A, Khan MA, Ahmad M, Zafar M, Ahmad F. Indigenous uses of economically important flora of Margallah hills national park, Islamabad, Pakistan. Afr. J. Biotechnol. 2009;8(5):763-84.

64. Shinwari MI, Khan MA. Folk use of medicinal herbs of Margalla hills national park, Islamabad. J Ethnopharmacol. 2000;69(1):45-56. https://doi.org/10.1016/S0378-8741(99)00135-X

65. Bahadur A. Ethno-Medicinal study of Merbazghaz Jahangir abad, Mardan, Khyber Pukhtoonkhwa, Pakistan. Int J Pharma Res Development. 2012;4(1):129-31.

66. Mosaddegh M, Naghibi F, Moazzeni H, Pirani A, Esmaeili S. Ethnobotanical survey of herbal remedies traditionally used in Kohghiluyeh va Boyer Ahmad province of Iran. J Ethnopharmacol. 2012;141(1):8095. https://doi.org/10.1016/j.jep.2012.02.004

67. Naveed S, Hussain F, Khattak I, Badshah L. Floristic Composition and Ecological Characteristics of OleaAcacia Forest of Shamshokii District Karak. Global Journals Inc. 2012;12(8):31-6.

68. Haq F, Ahmad H, Alam M. Traditional uses of medicinal plants of Nandiar Khuwarr catchment (District Battagram), Pakistan. J. Med. Plants Res. 2011;5(1):39-48.

69. Jan G, Jan FG, Hamayun M, Khan K, Khan A. Diversity and conservation status of vascular plants of Dir Kohistan valley, Khyber Pakhtunkhwa Province. Journal of Biodiversity and Environmental Sciences 2014;5(1):164-72.

70. Chandra S, Rawat D. Medicinal plants of the family Caryophyllaceae: a review of ethno-medicinal uses and pharmacological properties. J. Integr. Med. 2015;4(3):123-31.

https://doi.org/10.1016/j.imr.2015.06.004

71. Shah SM, Hussain F. Ethnomedicinal plant wealth of Mastuj valley, Hindukush range, District Chitral, Pakistan. J. Med. Plants Res. 2012;6(26):4328-37. https://doi.org/10.5897/JMPR12.527

72. Kumar S, Chand G, Sankhyan P, Chaudhari Manojkumar V, Gupta V, Keshari BB, et al. Herbal folk remedies for curing various ailments in Lug Valley of district Kullu, Himachal Pradesh (NW Himalaya). Int. j. Ayurvedic herb. Med. 2013;3(5):1308-14.

73. David M, Ain Qu, Ahmad M, Zaman W, Jahan S. A biochemical and histological approach to study antifertility effects of methanol leaf extract of Asplenium dalhousiae Hook. in adult male rats. Andrologia 2019;51(6):e13262. https://doi.org/10.1111/ and.13262

74. Zaman W, Ahmad M, Zafar M, Amina H, Lubna, Ullah $\mathrm{F}$, et al. The quest for some novel antifertility herbals used as male contraceptives in district Shangla,
Pakistan. Acta Ecol. Sin. 2019:1-11. https://doi.org/10.1016/j.chnaes.2019.05.017

75. Zaman W, Shah SN, Ullah F, Ayaz A, Ahmad M, Ali A. Systematic approach to the correct identification of Asplenium dalhousiae (Aspleniaceae) with their medicinal uses. Microsc Res Techniq. 2019;82(4):45965. https://doi.org/10.1002/jemt.23189

76. Ali Z, Ahmad VU, Ali MS, Iqbal F, Zahid M, Alam N. Two new C-glycosylflavones from Silene conoidea. Natural Product Letters 1999;13(2):121-9. https://doi.org/10.1080/10575639908048832

77. Zibareva L, Volodin V, Saatov Z, Savchenko T, Whiting $\mathrm{P}$, Lafont R, et al. Distribution of phytoecdysteroids in the Caryophyllaceae. Phytochemistry 2003;64(2):499517. https://doi.org/10.1016/S0031-9422(03)00376-5

78. Mamadalieva NZ, Lafont R, Wink M. Diversity of secondary metabolites in the genus silene $\mathrm{L}$. (Caryophyllaceae)-Structures, distribution, and biological properties. Diversity 2014;6(3):415-99. https://doi.org/10.3390/d6030415

79. Mamadalieva NZ. Phytoecdysteroids from Silene plants: distribution, diversity and biological (antitumour, antibacterial and antioxidant) activities. Boletín Latinoamericano y del Caribe de Plantas Medicinales y Aromáticas 2012;11(6):474-97.

80. Mehrabi B, Alimohamdai H, Farhadian Babadi M, Ghahremani Nejad F. Biogeochemical exploration in Sari Gunay gold deposit, Northwestern Iran Geopersia 2016;6(2):223-32.

81. Abbasi AM, Iqbal J, Khan MA, Shah MH. Health risk assessment and multivariate apportionment of trace metals in wild leafy vegetables from Lesser Himalayas, Pakistan. Ecotox Environ Safe. 2013;92:237-44. https://doi.org/10.1016/j.ecoenv.2013.02.011

82. Zarins I, Daugavietis M, Halimona J. Biological activity of plant extracts and their application as ecologically harmless biopesticide. Scientific works of the Lithuanian Institute of Horticulture and Lithuanian University of Agriculture. 2009;28(3):11.

83. Srujana TS, Babu KR, Rao BSS. Phytochemical investigation and biological activity of leaves extract of plant Boswellia serrata. The Pharma Innovation 2012;1(5):22-46.

84. Behzad S, Pirani A, Mosaddegh M. Cytotoxic activity of some medicinal plants from Hamedan district of Iran. IJPR. 2014;13(Suppl):199-205.

85. Datta AK, Mandal A, Ghosh BK, Saha A, Sengupta S, Paul R, et al. Meiotic novelty in Rhoeo spathacea var. bicolor (Swartz) Stearn (Commelinaceae). J. plant dev. sci. 2010;2(3\&4):77-82.

86. Akgöz Y. The effects of Hypericum (Hypericacea) species on microorganisms: A review. Int. Res. J. Pharm. 6(7):390-399.

87. Gatti AB, Ferreira AG, Arduin M, Perez SCGdA. Allelopathic effects of aqueous extracts of Artistolochia esperanzae O. Kuntze on development of Sesamum indicum L. seedlings. Acta Bot Bras. 2010;24(2):454-61. $\underline{33062010000200016}$

88. Bhatia R, Gill H, Mehra S. Allelopathic potential of some weeds on wheat. IJWS. 1982;14(2):108-14. 
89. Wani BA, Wani NA. Weed flora infesting saffron (Crocus sativus L.) fields of Pampore, kashmir. Report and Opinion. 2011;3(1):61-64

90. Singh S, Malik R, Balyan R, Singh S. Distribution of weed flora of wheat in Haryana. Indian J Weed Sci. 1995;27(3-4):114-21.

91. Ullah F, Ullah A, Sohail A. Medicinal and ecological diversity of weeds in wheat crop at Lower Dir, Pakistan. Pak J Weed Sci Res. 2016;22(4):627-37.

92. Yin L, Cai Z, Zhong W. Changes in weed composition of winter wheat crops due to long-term fertilization. Agriculture, Ecosystems \& Environment 2005;107(2):181-6. https://doi.org/10.1016/j.agee.2004.11.003

93. Kolar J, Mehra S. Changing scenario of weed flora in agroecosystems of Punjab. Ludhiana: Punjab Agricultural University; 1992. p. 252-62.

94. Turk M, Tawaha A. Weed control in cereals in Jordan. Crop Protection 2003;22(2):239-46. https://doi.org/10.1016/S0261-2194(02)00182-5

95. Liu X-f, Yang D-j, Li Y-t, Liang H-p, Zhen G-X. Analysis of Some Toxic Elements in Foods Produced in Shunyi District of Beijing [J]. Chinese Journal of Food Hygiene 2008;2:016.

96. Joginder S, Sandhu S, Singla M. Ecology of Heliothis armigera (Hub.) on chick pea in Punjab. J Insect Sci. 1990;3(1):47-52.

97. Oran SA. A list of flowering wild plants in Tafila Province, Jordan. International journal of Biodiversity and conservation 2014;6(1):28-40. https://doi.org/10.5897/IJBC2011.116

98. Shah SM, Ullah A, Hadi F. Ecological characteristics of weed flora in the wheat crop of Mastuj valley, District Chitral, Khyber Pakhtunkhwa, Pakistan. Pak J Weed Sci Res. 2014;20(4):479-87.

99. Khan M, Hussain F, Musharaf S. Preliminary floristic range of Tehsil Takht-e-Nasrati Pakistan. Int. J. Biosci. 2011;1(6):88-99.

100. Singh T, Sandhu K, Bhatia R. Weed flora of wheat fields in the Punjab. I J of Weed Science 1993;25(1\&2):17-21.

101. Akhtar N, Hussain F. Weeds of wheat fields of village Qambar, District Swat, Pakistan. Pak J Pl Sci. 2007;13(1):33-7.

102. Naeem S, Shad R, Sher M, editors. Correlation of soil macro-nutrients and micro-nutrients with weed flora of wheat under medium rainfall conditions. Fourth All Pakistan Weed Science Conference, Faisalabad (Pakistan), 26-27 Mar 1994; 1995: UAF.
103. Yu J-f, Wang J-x, Chen M-X, ZHU X-c. Studies on ecoeconomic thresholds of mixed-growing weeds in wheat fields. Plant Protection-Beijing- 2002;28(5):1314.

104. Musharaf, K., Abdur, R., \& Shahana, M. (2011). A fraction of angiosperms of Tehsil Banda Daud Shah district Karak Pakistan. JBES. 1(6), 128-154.

105. Qiang S. Multivariate analysis, description, and ecological interpretation of weed vegetation in the summer crop fields of Anhui Province, China. Integr Plant Biol. 2005;47(10):1193-210. https://doi.org/10.1111/j.1744-7909.2005.00131.x

106. Rawat D. Uphill journey of plants in the Himalaya. Curr. Sci. 2010;99(12):1644-5.

107. Abu-Irmaileh BE, Syouf M, Al-Fakhori S. 2, 4-D tolerant new weed species of Caryophyllaceae plant family. Crop Res. (0970-4884). 2015;49.

108. Jamshidi S, Ahmadifard S, editors. Estimating seed bank of weed in wheat-wheat and wheat-fallow rotations in rainfed winter wheat farms. Proceedings of International Conference on Asia Agriculture and Animal (ICAAA 2011); 2011.

109. Keshavarzi K. Distribution map of weeds in wheat dry land farms by geographical information system application (case study: Kohgiluyeh-va-Boyerahmad province, Iran). Agricultural Communications. 2015;3(4):16-22.

110. Kochar IK, Kumar M, Dhawan S. Association of weeds with major Rabi crops of district Sriganganagar. I J Weed Science 2009;41:220-21.

111. Ramachandra D, Ramamohan G, Bhan A, Suresh P. Weed management in cotton: The potential of GM crops. I J Weed Science 2016;48(2):136-43. https://doi.org/10.5958/0974-8164.2016.00035.6

112. Qasem J. Chemical control of wild-oat (Avena sterilis L.) and other weeds in wheat (Triticum durum Desf.) in Jordan. Crop protection 2007;26(8):1315-24. https:// doi.org/10.1016/esj.cropro.2006.11.006

113. Xian Y, Peicong G, Baoqing L. Effects of NK interaction on yield, quality and uptake of nitrogen, phosphorus and potassium in potato (Solanum tuberosum L.) Journal of South China Agricultural University 1993.

114. Lian H, Liu T, Ma G-S, Liu F, Jin Y-Z. Effects of Combined Application of Nitrogen and Potassium on Morphological Indicators and Yield of Silene conoidea L. Northern Horticulture 2013;19:053. 